\title{
A primer Sjögren-szindróma pszichológiai vonatkozásai
}

\author{
V. Módis László dr. ${ }^{1,2}$ - Szántó Antónia dr. ${ }^{2}$ - Bugán Antal dr. ${ }^{1}$ \\ ${ }^{1}$ Debreceni Egyetem, Általános Orvostudományi Kar, Magatartástudományi Intézet, Debrecen \\ ${ }^{2}$ Debreceni Egyetem, Általános Orvostudományi Kar, Belgyógyászati Intézet, Klinikai Immunológiai Tanszék, \\ Debrecen
}

\begin{abstract}
A primer Sjögren-szindróma (pSS) krónikus autoimmun betegség, melynek elsődleges tünetei az exokrin mirigyeket érintő autoimmun folyamat következtében létrejövő szem- és szájszárazság, szisztémás manifesztációi között pedig a leggyakoribbak a szellemi és fizikai fáradtság és az ízületi fájdalmak. A betegség lélektani vonatkozásait nagy érdeklődés övezi; közleményünk a vonatkozó kutatási eredményeket foglalja össze a hátterükben húzódó pszichoneuroimmunmodulációs háttér rövid bemutatásával. A pSS pszichológiai tényezői közt a legrégebben vizsgáltak a depresszió és a szorongás. Ezek jelentős hatással vannak a betegek életminőségére, jóllétére, kognitív funkcióira, sőt a betegség aktivitására is. Bemutatjuk továbbá a stressz és a megküzdési stratégiák jellegzetes mintázatait pSS-ben, amelyek közt a betegségre jellemző maladaptív stratégiák a legjelentősebbek a patogenezis megértése és a kezelés szempontjából. Ilyenek a tagadás, a hasítás és a helyettesítés. Kitérünk a Sjögren-szindrómát kísérő személyiségjellemzőkre is, amely ígéretes terület, de kevés adat áll rendelkezésünkre; az eddigi vizsgálatok alapján a neuroticismus a leginkább pSS-re jellemző tényező. A kognitív funkciók érintettségének összefoglalása és az egyéb pszichológiai tényezők (szellemi fáradtság, szexualitás, testképzavar, életminőség) összegzése után egyértelmúen levonható a következtetés, hogy a Sjögren-szindróma nemcsak biológiai, hanem pszichés, pszichoszociális és szociális jelenségszinteken is okoz zavarokat, tüneteket. Ezért rendkívül fontos a betegség biopszichoszociális szemléletú kezelése, a betegek aktív, intencionális részvétele a pSS-sel való megküzdésben.
\end{abstract}

Orv Hetil. 2021; 162(39): 1558-1566.

Kulcsszavak: Sjögren-szindróma, affektív tünetek, pszichológiai adaptáció, személyiség, magatartásorvoslás

\section{Psychological features of primary Sjögren syndrome}

Primary Sjögren syndrome (pSS) is a chronic, autoimmune disorder. Primary symptoms are ocular and oral dryness as a of an autoimmune process affecting the exocrine glands. The most common systemic manifestations of the disease are mental and physical fatigue and arthralgia. Psychological features of pSS are studied with great interest; the present publication reviews the results of the related investigations alongside with the possible psychoneuroimmunomodulatory background. Among psychological factors in pSS, depression and anxiety have been studied the longest. These impact significantly the quality of life, wellbeing, cognitive functions and disease activity of the patients. Afterwards, we introduce the characteristic patterns of stress and coping mechanisms in pSS, among which maladaptive strategies, typical for the disorder are the most important regarding the pathogenesis and the therapy. These pSS-linked maladaptive strategies are denial, disengagement and focus and venting of emotions. As next, we give a summary about personality characteristics in pSS, which is a promising field to study, and yet very few related data are available; based on them, neuroticism seems to be the most common personality factor in Sjögren's. After summarizing briefly cognitive functions and other psychological features (mental fatigue, sexuality, body image disturbance and quality of life), it is evident that pSS is determined not only by biological but also by psychological, psychosocial and social disturbances. Hence, treating pSS patients with a biopsychosocial perspective is crucial and so is the active and intentional participation of patients in their recovery.

Keywords: Sjögren's syndrome, affective symptoms, psychological adaptation, personality, behavioral medicine

V Módis L, Szántó A, Bugán A. [Psychological features of primary Sjögren syndrome]. Orv Hetil. 2021; 162(39): $1558-1566$.

(Beérkezett: 2021. március 2.; elfogadva: 2021. március 19.) 


\section{Rövidítések}

ACTH $=$ (adrenocorticotropic hormone) adrenokortikotrop hormon; $\mathrm{AMPA}=$ alfa-amino-3-hidroxi-5-metil-4-izoxazolpropionsav; AQP5 $=($ aquaporin 5$)$ akvaporin -5 ; BNST $=($ bed nucleus of the stria terminalis) a stria terminalis dorsolateralis ágymagva; $\mathrm{EPQ}=$ (Eysenck Personality Questionnaire) Eysenck-féle Személyiség-kérdőív; HPA = hypothalamo-hypophyseo-adrenocorticalis; HPG = hypothalamo-hypophyseogonad; IFN = interferon; IL = interleukin; LOI = (Leyton Obsessional Inventory) Leyton Obszesszivitásleltár; MMPI = (Minnesota Multiphasic Personality Inventory) Minnesota Többfázisú Személyiségleltár; MSH = melanocytastimuláló hormon; NEO PI-R = (Revised NEO Personality Inventory) Felülvizsgált NEO Személyiségleltár; NPY = neuropeptid Y; pSS = (primary Sjögren syndrome) primer Sjögren-szindróma; $\mathrm{TNF}=$ tumornekrózis-faktor; VIP = vasoactiv intestinalis peptid

A Sjögren-szindróma az autoimmun betegségek családjába tartozó krónikus exocrinopathia, melynek primer (glandularis és extraglandularis tünetek együttese) és szekunder (egyéb szisztémás autoimmun kórképpel társuló) formája ismert. Fő ismertetőjegye a külső elválasztású, elsősorban a nyál- és könnymirigyek lymphoplasmacytás infiltrációja, amely kialakítja jellegzetes klinikai manifesztációját: a sicca- és a szisztémás tüneteket. A pSS patogenezise mindmáig tisztázatlan; a legújabb modell szerint az „autoimmun epithelitis” kifejezés írja le a legpontosabban a betegség etiológiáját, utalva arra, hogy a nyálmirigyek epithelsejtjei aktívan részt vesznek a betegség kialakulásában [1].

Prevalenciáját $0,1 \%$ és $4,8 \%$ közé becsülik $[2,3]$, így a leggyakoribb kötőszöveti autoimmun betegség a rheumatoid arthritis után. Nemek közötti megoszlása $9: 1$ arányú női túlsúlyt mutat [4]. A jelen összefoglalóban a primer Sjögren-szindróma (pSS) pszichológiai jellegzetességeit foglaljuk össze. Említést teszünk a szekunder formákról is, azonban ezen állapotok patogenezise és kórlefolyása oly mértékben összetett, hogy esetükben lehetetlen a Sjögren-szindróma tüneteit izoláltan, az alapbetegségtől elkülönítve vizsgálni. Ezért részleteiben a primer kórképre jellemzó lélektani vonatkozásokat ismertetjük. Tudomásunk szerint ez az első, magyar nyelven elkészült tanulmány ebben a témában.

$\mathrm{Az}$ autoimmun betegségek lelki meghatározottsága régóta ismert. Franz Alexander magyar származású pszichiáter már 1950-ben a „pszichoszomatikus hétszentség” közé sorolta a leggyakoribb autoimmun reumatológiai megbetegedést, a rheumatoid arthritist [5]. Később külön tudományág, a pszichoneuroimmunológia kezdte vizsgálni a lélek, a központi idegrendszer és az immunrendszer kölcsönhatásait [6]. Valószínúleg ezen három rendszer komplex kölcsönhatásaiból alakul ki az a klinikai kép, amelyet a szisztémás autoimmun betegségek esetében láthatunk: a testi panaszok mellett jelen vannak pszichológiai tünetek is, mind affektív (például depreszszió és szorongás) $[7,8]$, mind kognitív (például memó- ria és figyelem) [9], mind pedig viselkedési (például megküzdési módszerek, betegségbelátás) $[10,11]$ szinten.

Az orvosi pszichológiai vizsgálatok tárgya ezeken a jelenségszinteken túl az egyes betegségekre jellemző személyiségtípusok, személyiségjellemzők feltárása. A szisztémás autoimmun betegségek közt a rheumatoid arthritisben szenvedő betegek személyiségtípusáról van messze a legtöbb információnk [12-15], de vannak tanulmányok a Sjögren-szindrómára jellemző személyiségtípusról is $[16,17]$, amelyek a későbbiekben részletesen is bemutatásra kerülnek.

\section{A probléma biológiai megközelítése: neuroimmunmoduláció Sjögren- szindrómában}

\section{Az idegrendszer hatásai az immunmüködésre}

A témában zajlott kutatások nyomán kirajzolódik egy olyan komplex kölcsönhatás, amelyben az agy és az immunrendszer kölcsönösen befolyásolják egymás múködését. Az agy immunrendszerre gyakorolt egyik közvetlen funkciója a nyirokszervek beidegzése. Ezt a mechanizmust vizsgálták Tracey és mtsai, akik leírták az antiinflammatoricus reflexet [18]. A reflex afferentatiója a veleszületett immunrendszer aktivált sejtjeinek proinflammatoricuscitokin-termelése, az efferens szárát pedig azon kolinerg efferens neuronok képezik, amelyek ugyanazon sejtek citokintermelését visszaszorítják. Ezt a teóriát a mai napig nem sikerült hitelt érdemlően bizonyítani. Ellene szól, hogy ismereteink szerint a nyirokszerveknek elenyésző a paraszimpatikus beidegzése a bélrendszer nyirokszerveit kivéve. Szimpatikus beidegzés a lép esetében is szórványosan fordul elő. Ennek egy lehetséges feloldása, hogy a nervus vagus stimuláció hatására valóban végbemegy a lymphocyták toborzása a bélben, és ezután ezek az aktivált T-sejtek vándorolnak az egyéb szervek felé, többek között a lépbe [19].

A központi idegrendszer immunrendszerre gyakorolt hatásai közt megemlítendő a katecholaminok szabályozó szerepe. A pSS patogenezisében kulcsszerepet játszó Thl-lymphocyták és progenitoraik, a CD4+ T-sejtek elsősorban $\beta 2$-adrenerg receptorokat fejeznek ki. A naiv CD4+ T-lymphocyták noradrenalin $\beta 2$-adrenerg receptoron keresztüli hatásra Thl-sejtekké alakulnak át megnövekedett interferon- $\gamma$ (IFN $\gamma$ )-termeléssel [20]. A szimpatikus beidegzés kémiai denervációja pedig csökkenti a késői (IV.) típusú túlérzékenységet, amelyben szintén szerepet játszanak a Thl-lymphocyták [21]. A lymphocyták maguk is képesek katecholamintermelésre, sốt azt is megfigyelték, hogy az aktivált lymphocyták fokozzák a katecholamintermelést is [22]. Ezáltal parakrin és autokrin adrenerg és noradrenerg szabályozó mechanizmusok is végbemennek a lymphocytafunkció regulációjában. Mindezek alapján valószínűsíthető, hogy a 
katecholaminok Thl-sejtekre gyakorolt hatásain keresztül ezek a molekulák befolyásolják a pSS kialakulását, lefolyását.

A harmadik és valószínúleg a legfontosabb útvonal, amelyen keresztül a központi idegrendszer befolyásolja az immunrendszer múködését, a neuroendokrin múködés. Ezen belül is nagy szerep jut a glükokortikoidok szabályozó szerepének. Ezek a hormonok a hypothalamo-hypophyseo-adrenocorticalis (HPA-) tengelyen keresztül létesítenek kapcsolatot a központi idegrendszer és a periféria között [23]. A HPA-tengely érintettsége okozhatja a stresszel való megküzdés (coping) gyengülését, ezáltal pedig a pSS-ben tapasztalt pszichológiai változásokat is. Ezt a neuroendokrin változást kísérletekkel is alátámasztották: egy 1998-ban megjelent tanulmányban leírták a pSS-ben szenvedő betegek alacsony ACTHés glükokortikoidszintjét, valamint a HPA-tengely hipofunkcióját [24]. A glükokortikoidok a thymusban a CD4+ és CD8+ sejtek apoptózisát, valamint masszív involúciót eredményeznek [25]; így a HPA-tengely alulmúködése következtében visszaszorul a pSS patogenezisében részt vevő Thl-sejtek előalakjának eliminációja.

A glükokortikoidok az endokrin szabályozás mellett képesek parakrin és autokrin módon is részt venni az immunrendszer modulációjában. Ehhez nagyban hozzájárul a mellékvesén kívüli, azaz az extraadrenalis glükokortikoidszintézis. Ezt a jelenséget először a thymusban figyelték meg. A thymus által termelt glükokortikoid képes lokálisan szabályozni a thymocyták fejlődését, illetve a naiv T-sejtek képzésének gyorsaságát. A folyamat autonómiájához hozzájárul, hogy független a keringó glükokortikoidok szintjének mértékétől [26].

A HPA-tengely mellett számos hormonális hatás segíti a központi idegrendszer és az immunrendszer kommunikációját. A tény, hogy a betegség elsősorban perimenopausalis korban lévő nőket érint, és klinikai kutatások is alátámasztják az ösztrogén és a hypothalamo-hypophyseo-gonad (HPG)-tengely szabályozó szerepét a betegségben [27]. Az ösztrogén hatása az exokrin mirigyekre közvetlen: segíti a T-sejtek toborzását [28], megelőzi az apoptózist a könnymirigyekben [29], és az ajak belső felszínén lévő nyálmirigyek acinusában is fokozódik az apoptózis ösztrogén hiányában [30].

Ezeken felül a neuroendokrin szabályozásnak van lokális formája is. A nyálmirigyekben számos neuroendokrin funkcióhoz köthető molekula fejeződik ki. Ilyenek a

1. táblázat |A nyálmirigyek lokális neuroendokrin szabályozásában részt vevő molekulák

Acetil-kolin
Noradrenalin
Neuropeptid Y (NPY)
P-anyag
Hisztidin-metionin peptid (PHM)
Acetil-kolin-receptorok
Muszkarinos receptorok (M1 és M3)

muszkarinos és a kolinerg receptorok, de a neuropeptid Y (NPY) [31] és a vasoactiv intestinalis peptid (VIP) [32] is része a lokális neuroendokrin múködésnek. Ezek közül a molekulák közül a nyálmirigyek patológiájára a VIP van a legnagyobb hatással: pSS egérmodelljében a VIP-kezelés nemcsak az immunreakciót szüntette meg az IL17A gátlásán keresztül, hanem a szekretoros funkciót is segítette az akvaporin-5 (AQP5) expressziójának fokozásával [33] (1. táblázat).

\section{Az immunmüködés központi idegrendszeri batásai}

Az ideg- és az immunrendszer kapcsolata természetesen nem merül ki a központi idegrendszer immunmúködésre gyakorolt hatásaiban, hiszen a kapcsolat a két entitás közt kölcsönös. Ennek kézenfekvő példája a fertőző betegségek során kialakuló láz. Az autoimmun kórképekben, így Sjögren-szindrómában az immunrendszer hatása a HPA-tengelyre ugyanolyan fontos, mint a központi idegrendszer HPA-tengelyen keresztül történő szabályozó múködése. Így tehát egy, a HPA-tengelynél komplexebb rendszer, az immun-hypophyseo-adrenocorticalis rendszer képe is kirajzolódik előttünk [34].

A proinflammatoricus citokinek magatartásra gyakorolt hatásának eredményeképp alakul ki a betegségmagatartás. A betegségmagatartás általában fertóző betegségekben alakul ki; vannak kutatások, amelyek a Sjögren-szindróma ismert tüneteként jelentkező szellemi fáradtság hátterében is ezt a jelenséget feltételezik [35]. A betegségmagatartás gyulladásos mediátorai a gyulladt területet beidegző afferens neuronokon keresztül jutnak az agyba [36]. A betegségmagatartás befolyással van a szociális interakciókra is: immunstresszor (bakteriális lipopoliszacharid) hatására a szociális aktivitás csökkenését írták le patkányok esetében, amit az előagyban termelt ILl-nek a centrális amygdalára és a stria terminalis dorsolateralis ágymagvára (BNST) kifejtett hatása váltott ki [37].

A citokinek azonban nemcsak immunhatásra jelennek meg az agyban, hanem folyamatosan jelen vannak, és szerepet játszanak a szinapszisok fiziológiájában és plaszticitásában. Jól mutatja ezt az a megfigyelés, hogy a gliasejtek által termelt TNF $\propto$ konstitutív szabályozó szerepet játszik az alfa-amino-3-hidroxi-5-metil-4-izoxazol-propionsav (AMPA)-receptorok sejtfelszíni kifejeződésében hippocampalis neuronokban [38]. A TNF konstitutív expressziójáról kiderült, hogy a korábbi vélekedéssel ellentétben nem a neuronokban, hanem a microgliasejtekben megy végbe. Ezek a sejtek elengedhetetlenek a fiziológiás szinaptikus funkció kialakulásához és múködéséhez, és homeosztázisukban nemcsak a TNF, hanem más citokinek (például IL34) is fontos szerepet játszanak. A microgliának tehát központi szerepe van a citokinek központi idegrendszerre, különösen a szinaptikus plaszticitásra gyakorolt hatásának közvetítésében. 
Összefoglalásként elmondható, hogy az ideg- és az immunrendszer komplex kölcsönhatásrendszere jellemző pSS-ben. A betegség kialakulásáért felelősnek tartott immunológiai mechanizmusok nemcsak szisztémás hatásokkal bírnak, központi idegrendszeri hatásaik is jelentősek. Ezek között a hatások között nem egy a limbicus rendszert célozza, ami felelőssé tehető a pSS affektív tüneteiért, míg a neuroendokrin múködések érintettsége inkább a stresszel való megküzdés maladaptív formáiban játszhat nagyobb szerepet. A neurobiológiai tényezók magyarázatul szolgálhatnak a pszichológiai jelenségek részleteire, azonban ezek a komplex jelenségek, amelyeket a későbbiekben bemutatunk, nem vezethetők vissza egyértelmú idegrendszeri változásokra.

\section{Depresszió és szorongás}

A Sjögren-szindrómában jelentkező pszichés zavarok közül a legrégebben ismertek a depresszió és a szorongás [39, 40]. A krónikus betegségek a kialakulásukra való tekintet nélkül a depresszió rizikófaktorainak számítanak, pSS-ben azonban ezt még fokozza a személyiségjegyek közt leírt magas neuroticismus is. A pSS szisztematikus manifesztációi, a kimerültség és az alvászavar, szintén depresszióra hajlamosító tényezők [41, 42].

A depressziós tüneteket mutató pSS-betegek magasabb betegségaktivitással és gyorsult erythrocytasüllyedési értékekkel rendelkeznek, gyakoribb köztük a munkanélküliség, általában alacsonyabb iskolai végzettségúek, és súlyosabb fájdalmakról számolnak be depresszió nélküli társaikhoz képest [43]. A depresszió és a betegség viszonyáról azonban megoszlanak a vélemények: van olyan szerző, aki arról számol be, hogy pSS-ben és kimutatható autoimmun folyamat nélküli siccaszindrómás betegek közt nincs szignifikáns eltérés a pszichológiai statusban, és egyik csoport sem különbözik számottevően a hozzájuk korban közel álló, egészséges női csoport válaszadóitól [44]. A két csoport közti összehasonlításban figyelmet érdemel, hogy míg a szubjektív szárazságérzés közel azonos egymáshoz, addig a pSS-ben szenvedő betegek objektív Schirmer-tesztje nagyobb fokú szárazságot mutat, mint az autoimmun folyamat nélküli siccaszindrómásoké [45].

A betegségben jelentkező depresszió a kognitív funkciókra is hatással van; depresszióban érintett Sjögrenszindrómás betegek esetében rosszabb a végrehajtó funkció, a munkamemória és a verbális memória a nem depressziós páciensekhez képest [46].

A depresszióval általában együtt vizsgált szorongás a pSS gyakori velejárója $[43-45,47]$, és egyes vizsgálatok szerint sürübben fordul elő, mint a depresszió [45]. A pSS-hez társult szorongás összefügg az $\propto \mathrm{MSH}$ elleni magas antitestszinttel, ami valószínúsíti a melanokortinrendszer diszregulációjának szerepét a szorongás kialakításában [48]. Ezt alátámasztja a tény, hogy a melanokortinrendszernek a viselkedésre és az affektív állapotokra gyakorolt hatása korábbról is ismert. Egy kí- nai mintán végzett tanulmány szerint a szorongásra leginkább az oralis egészség és a nyelési zavarok hatnak a pSS tünetei közül [43]. A betegségben fellépő szorongás természetesen hat a betegek életminőségére is [49]. Számos vizsgálat történt annak érdekében, hogy megállapítsa: tapasztalható-e szorongás a pSS-betegek körében, és sikerrel is jártak, hiszen mostanra tudományosan is alátámasztott tényként kezelhetjük, hogy pSS-ben nagyobb a szorongás kialakulásának valószínúsége; azonban elenyésző olyan jellegű információnk van, hogy mi a szorongás tartalma, milyen tényezők váltják ki a betegek életében a szorongásos panaszokat. Ennek feltárása új irány lehet a Sjögren-szindrómához társult szorongás vizsgálatában.

\section{Stressz és megküzdési stratégiák}

Megküzdési (coping) stratégiáknak azokat a viselkedéses vagy kognitív (és érzelmi) erőfeszítéseket nevezzük, amelyek segítségével az egyén képes megbirkózni a stresszt keltő életeseményekkel [50]. A témában 2001ben, Svédországban készült átfogó tanulmány leír jó néhány, pSS-ben szenvedő betegekre jellemző szituációs megküzdési mintázatot [51]. Kísérletükben megkérték a betegeket, hogy oldjanak meg olyan teoretikus helyzeteket, melyekben jelen van a pSS-re jellemző valamilyen stresszor. A legjelentősebb stresszor - elsősorban azok között a betegek között, akiknek volt munkájuk - a szellemi fáradtság volt, amely az esetek nagy részében levertséggel, tehetetlenséggel és az izoláció felé tartó tendenciával társult. A szellemi fáradtságot vizsgáló szituációkban a betegek általában „harcos szellemet” mutattak, nagyon szerettek volna megküzdeni a helyzetekkel. A szerzők a társas támogatás meglétét kimagaslóan fontosnak találták az adaptív megküzdési stratégiák kialakításához. A szellemi fáradtság a másik három legkimagaslóbb értéket mutató stresszorral - a szem, valamint a száj szárazságával és az alvászavarokkal -, továbbá minden egyéb stresszforrással egyetemben nagyobb mértékben befolyásolja a betegek életminóségét, mint az a szakirodalomból kitűnik. A stresszforrások között meg kell emlékezni a szociális és a pszichoszociális stresszról is. Ezek közt kimagasló helyen van a munkanélküliség, amit sok tanulmány kiemel $[17,52,53]$, valamint az iskolázottság is. Nem kerülheti el a figyelmünket, hogy a betegség 9 : l arányban gyakrabban fordul elő nóknél, valószínű tehát, hogy a nők társadalmi helyzete, nehezebb munkavállalási esélyei is hozzájárulhatnak a betegek stresszforrásaihoz. A bekezdés elején hivatkozott svéd tanulmány azt is kimutatta, hogy a részt vevő betegek átlagosan mért stressz-szintje magasabb volt, mint a daganatos betegek esetében mért átlagos adatok.

Ezt a megfigyelést később is alátámasztották: nemcsak a pSS kialakulása előtti egy évben mértek szignifikáns növekedést a negatív, stresszes életesemények feltárása során, hanem összességében több negatív életeseményt találtak az egész életút vizsgálatakor [54]. Ezek közül a leggyakrabban a közeli hozzátartozó (közeli családtag 
vagy házastárs) volt a legnagyobb distresszforrás pSS-betegek esetében egészséges és beteg (lymphomában szenvedő) kontrollcsoporttal való összehasonlítás után. A stressz fokozott jelentőségű a neurobiológiai alapok című részben ismertetett neuroimmunológiai szabályozás tükrében is.

A pSS-betegek premorbid megküzdési stratégiáit elemző vizsgálat olyan maladaptív stratégiákat talált, mint a tagadás (a valóság elutasítása), mentális és viselkedéses hasítás (megnövekedett tartózkodás az emocionális distressztől, az olyan célra irányuló erőfeszítések hanyagolása, amelyek a stresszorral kapcsolatban állnak), valamint az érzelmek helyettesítése, más területeken való kitöltése (a hasítással együtt járó stratégia, a stresszorral kapcsolatos érzelmektől való megszabadulás) [54]. Ez a megküzdési mintázat elsősorban a személyiségvonásokkal függ össze, nem annyira a betegség lefolyásával, így arra következtethetünk belöle, hogy a pSS-betegek rendelkeznek karakterisztikus személyiségjellemzőkkel [17].

\section{Személyiség}

Mint az előzőekből kitűnik, a személyiség szerepe nem kerülhető meg a pSS pszichológiai vonatkozásainak tárgyalása során. A Sjögren-szindrómára jellemző személyiségszerkezetet vizsgáló kutatások közül az egyik első az MMPI segítségével kimutatta, hogy pSS-betegek közt növekedés tapasztalható a hypochondria (Hs), a hisztéria (Hy) és a depresszió (D) klinikai alskálákon. Ez a mintázat megfelel az ún. V típusú konverziónak, amelyet öszszefüggésbe hoztak pszichogén fájdalommal is [55], és általában olyan szomatizációs vagy konverziós képet jelöl, amelyben dysphoriás tünetek figyelhetők meg [56]. Később megerősítették ennek a három alskálának a kiugró értékét finn mintán is pSS-ben [57], azonban míg Malinow és mtsai a három jellemző skála közül a hypo- chondriát és a hisztériát találták hangsúlyosnak [39], addig Hietabarju és csoportja a depressziónak tulajdonít nagyobb jelentőséget [57]. A két kutatás eredményei azonban így is 77\%-ban megegyeznek.

A pSS-re jellemző személyiséget vizsgálták az Eysenck-féle Személyiség-kérdőívvel (EPQ) is. Ennek eredményeképpen pSS-re jellemző személyiségvonásnak mutatkozott a psychoticismus és a neuroticismus. Ugyanezen vizsgálat az obszesszivitást is a pSS korrelátumának mutatta (LOI); a hypochondria mint pszichopatológiai tényező szerepét ez pedig megerősítette, amiből a szerzők arra következtetnek, hogy a betegség kialakulásában nagy szerepet játszanak a premorbid személyiségjellemzók [48]. Egy közelmúltban megjelent szerb tanulmány megerősíti a magas neuroticismusértéket pSS-ben ötfaktoros modellben (NEO PI-R) történt vizsgálatok alapján; ezenfelül beszámol csökkent extroverzió- és barátságosságértékekről. A szerzők leírják, hogy a pSS-re jellemző személyiségvonások hasonlóságot mutatnak a rheumatoid arthritises betegekéivel. Mindezek alapján elmondható, hogy a Sjögren-szindrómára jellemző személyiségképről az adatok meglehetősen hiányosak, de a rendelkezésre álló eredmények biztatóak arra nézve, hogy valószínúleg vannak olyan személyiségjegyek, amelyek jellemzőek erre a betegségre, és módosítják annak kialakulását, lefolyását (2. táblázat).

\section{Kognitív funkciók}

Bár a jelen dolgozat kereteit meghaladja a pSS és a kognitív funkciók kapcsolatának részletes ismertetése, a betegségben való jelentős szerepük miatt néhány szót ejtenünk kell ezekről is. A jellemző tünetek közül a szellemi fáradtság [58], a fájdalom [46] és a depresszió [59] mind összefüggenek a kognitív múködés zavaraival. A leggyakoribb és legfontosabb ilyen természetű elváltozás a vég-

2. táblázat |A rendelkezésre álló vizsgálati eredmények a pSS-betegek személyiségéről

\begin{tabular}{|c|c|c|c|c|c|}
\hline \multirow[t]{2}{*}{ Vizsgálat } & \multirow[t]{2}{*}{ Eszköz } & \multirow[t]{2}{*}{ Elemszám } & \multicolumn{2}{|l|}{ Eredmények } & \multirow{2}{*}{$\begin{array}{l}\text { Előfordulás a vizsgálati } \\
\text { csoportban (n }[\%])\end{array}$} \\
\hline & & & Személyiségjellemző & Mért érték & \\
\hline \multirow[t]{3}{*}{ Malinow és mtsai, 1985* } & MMPI & 30 & Hypochondria & $72,3 \pm 12,1$ & $21(70,0)$ \\
\hline & & & Depresszió & $70,6 \pm 13,9$ & $14(46,6)$ \\
\hline & & & Hisztéria & $76,2 \pm 14,3$ & $21(70,0)$ \\
\hline \multirow[t]{3}{*}{ Hietaharju és mtsai, 1990* } & MMPI & 43 & Hypochondria & $69,8 \pm 11,3$ & $18(41,9)$ \\
\hline & & & Depresszió & $70,7 \pm 11,8$ & $24(55,8)$ \\
\hline & & & Hisztéria & $65,0 \pm 11,2$ & $10(23,3)$ \\
\hline \multirow[t]{3}{*}{ Karaiskos és mtsai, 2010** } & EPQ & 103 & EPQ, neuroticismus >12 & $4,41(2,37 ; 8,20)$ & $51(49,5)$ \\
\hline & LOI & & EPQ, psychoticismus $>2$ & $2,89(1,59 ; 5,25)$ & $46(44,7)$ \\
\hline & & & Obszesszivitás $(\mathrm{LOI})>10$ & $2,78(1,35 ; 5,74)$ & $28(27,2)$ \\
\hline Milic és mtsai, 2019** & NEO PI-R & 105 & Neuroticismus $\geq 96$ & $3,025(1,47 ; 6,21)$ & $54(48,6)$ \\
\hline
\end{tabular}

*A mért értékek az átlagos T-értéknek felelnek meg, mellettük a szórásértékek vannak feltüntetve.

**A mért értékek esélyhányadosként értelmezendők, mellettük zárójelben a 95\%-os konfidenciaintervallum két szélsőértéke szerepel.

EPQ = Eysenck-féle Személyiség-kérdőív; LOI = Leyton Obszesszivitásleltár; MMPI = Minnesota Többfázisú Személyiségleltár; NEO PI-R = Felülvizsgált NEO Személyiségleltár; pSS = primer Sjögren-szindróma 
rehajtó funkciók zavara: ez az életvitelt is megnehezíti, zavarja a munkavégzést és a napi feladatok ellátását. Így nemcsak önmagában jelent problémát, hanem visszahat a pszichoszociális tényezőkre is. Fontos zavar továbbá a verbális memória diszfunkciója; ezzel kapcsolatban érdekes megfigyelés, hogy a depresszióval korrelációban fordul eló pSS-ben [46]. A kognitív tünet kialakulhat a depresszió következményeképpen, de az is elképzelhető, hogy az agyi immunhatások folyományaképp jelentkezik mindkét tünet.

A betegségre vonatkozó kogníciók szerepe nagyon fontos a betegek életminőségének alakulása szempontjából. Szoros összefüggést mutattak ki a fizikai tünetek, a fájdalom katasztrofizálása és a negatív betegségértékelés között, amiből kitűnik, hogy a betegségre irányuló kognitív tartalmak jelentősen befolyásolják a pSS-betegek állapotát [60]. A betegségtudat jelentősebben befolyásolja a betegek életminőségét pSS-ben, mint más autoimmun betegségek (rheumatoid arthritis, szisztémás lupus erythematosus) esetében [61]. Ebból kifolyólag a Sjögren-betegek pszichoedukációja, terápiába való bevonása (különös tekintettel a kognitív viselkedésterápiára) több mint indokolt.

\section{Egyéb pszichológiai tünetek}

A pSS-ben jelentkező tünetek esetében sokszor nehéz megkülönböztetni, hogy biológiai vagy pszichológiai zavarról van-e szó, vagy éppen annyira komplex maga a jelenség, hogy több manifesztációs szintet is magában foglal. Az egyik ilyen tünet a szexualitás zavara, mely visszavezethető egyrészt a betegség részeként jelentkező vaginalis szárazságra, másrészt van mögötte pszichés komponens is. Egy 2017. évi felmérés szerint a pSS-ben szenvedő nőbetegek szignifikánsan elégedetlenebbek szexuális aktivitásukkal, mint egészséges társaik [62]. Ez a jelenség valószínúleg egy olyan biológiai háttérrel is rendelkező pszichoszexuális zavar, melynek patogenezise, hatása a női identitásra és a pszichoszociális állapotra nem ismert, felderítése értékes eredmény lehet a betegek gyógyítása szempontjából.

Egy másik összetett, több jelenségszinten megnyilvánuló tünet a szellemi fáradtság. A szellemi fáradtságról már ejtettünk szót a közlemény több pontján; ez a tünet teszi próbára a leginkább a betegek megküzdési viselkedését, és a legtöbb életvitelbeli kihívást okozza a betegségben (munkavégzés, napi feladatok), ami az életminőség fontos meghatározójává teszi. A betegek közül sokan ezt érzik betegségük legkínzóbb tünetének. Kezelésére nincs egyértelmú konszenzus, a szakirodalom a fáradtság leküzdésére szolgáló gyakorlatok tanítását, ilyen irányú tanácsadást ajánl a tünet enyhítésére [63]. Ebben az esetben is nagyon fontos a beteg aktív részvétele a betegségével való küzdelemben, felelősségvállalása a gyógyulás érdekében.

A betegség pszichológiájában fontos szerepet játszik a testkép és annak zavara is, hiszen a betegség olyan mor- fológiai és funkcionális változásokkal jár, amelyek hatással vannak a testhez való viszonyra. Ebben a témában meglehetősen kevés információ áll rendelkezésre; egy közelmúltban (2020) megjelent tanulmány arra hívja fel a figyelmet, hogy a Sjögren-szindrómához társuló testképzavart a leginkább a betegség aktivitása, az oralis egészség és a betegséggel együtt fellépő szorongás határozza meg. Ezen tünetek jelenlétében a beteget kezeló egészségügyi dolgozóknak figyelemmel kell lenniük a beteg lehetséges testképzavarára és annak kezelésére.

Napjaink egészségpszichológiai kutatásainak egyik céltáblájává vált az életminőségnek és a betegségek életminőségre gyakorolt hatásainak vizsgálata. A pSS esetében is számos kutatás zajlott és zajlik napjainkban is annak érdekében, hogy feltárják a betegség következményeit az életminőség vonatkozásában. Néhány eredményt már korábban is említettünk, így a betegség munkavégzésre gyakorolt hatását nem lehet eléggé hangsúlyozni a betegek szociodemográfiai tényezői között, és a női nem mint rizikófaktor felveti a férfiak és nők helyzetét a társadalomban, ami a nőbetegek esetében életminőséget meghatározó faktor. Holland mintán végzett kutatás során a Sjögren-szindrómás betegek 83\%-a számolt be alacsonyabb életminőségről a populáció átlagához képest. A kutatás eredményei értelmében a csökkent életminőség prediktorai a szellemi fáradtság, a tendomyalgia, az ízületi érintettség, a mesterséges nyál használata, antidepresszánsok szedése, valamilyen komorbiditás, a férfinem és a mozgáskorlátozottság kritériumainak való megfelelés voltak [64]. Egy kínai mintán történt vizsgálat a fájdalom és a szellemi fáradtság jelentőségére hívja fel a figyelmet [65]. A betegek életminősége olyan tényező, amelynek mérlegelése sokszor nehéz, és nagy erőfeszítést kíván, de fontos feladat a terápiás stratégia kialakításakor, különösen olyan komplex betegségek esetében, mint a Sjögren-szindróma. Éppen ezért a pSS életminőségre gyakorolt hatását vizsgáló kutatások végzése, illetve az egészségügyi szakdolgozók ilyen irányú ismerete egyaránt nagy jelentőségú.

\section{Megbeszélés, következtetések}

A pSS olyan komplex, szerteágazó patogenetikai faktorokkal és tünetekkel bíró kórkép, amelyben fontos szerep jut a pszichológiai tényezőknek. Láthattuk, hogy mind az affektív, mind a kognitív, mind a viselkedéses dimenzió érintett a betegségben. Bár sok adat áll rendelkezésünkre a pSS pszichológiájáról, sok olyan területe is van a témának, amely még feltárásra vár. Ilyen például sok lelki tényező elhelyezése a betegség kialakulásának oksági modelljében. Erre nézve vannak biztató eredmények, mint a fentiekben idézett, Karaiskos és mtsai által készített két tanulmány a megküzdési módszerekről [54] és a személyiségről [48], amelyek feltárnak olyan tényezőket, amelyek a betegségre prediszponálnak; ilyen eredményekból azonban még sokra van szükség, hogy a betegség testi-lelki múködését az oksági összefüggésekkel 
rendszerben láthassuk. A leírt és még kimutatásra váró tényezók komplex rendszere arra enged következtetni, hogy bonyolult, körkörös szabályozási viszonyok, a betegséget meghatározó tényezők előre- és visszacsatolásainak hálózata alakítja ki a pSS klinikai képét. Ez az összetettség megkívánja a cirkuláris okság szerinti gondolkodást a betegség kutatásában, kezelésében és megértésében, hiszen ez a rendszerszemléletú gondolkodásmód segíti a pSS-ről alkotott összetett, árnyalt kép kialakítását.

A lelki, pszichológiai tényezők mellett a Sjögrenszindróma fontos meghatározói a társadalmi, szociális és pszichoszociális vonatkozások. Ezek között kiemelkedik a munkanélküliség, valamint a betegség munkavégzésre gyakorolt hatása (elsősorban a szellemi fáradtság következtében), valamint a nói nem, ezáltal a nők társadalmi helyzete, a nők és férfiak helyzete a társadalomban. Ezek mind olyan szociális stresszorok, amelyek módosíthatják a betegség kialakulását, lefolyását.

A kutatások fontos további iránya a differenciáltabb, betegségspecifikusabb vizsgálatok elvégzése. Sok pszichológiai tünet (például szorongás, depresszió, életminőség) kimutathatóan jelen van a krónikus betegek életében. Vannak olyan személyiségjellemzők is, amelyek jellemzőek krónikus betegségekben. Ezek meglétét már alátámasztották, a következő lépésként az egy szinttel mélyebben meghúzódó, az egyes betegségekre jellemzó mintázatok feltárásának kell következnie. Ez lehet egyrészt a lelki tényezők mértéke, energiaszintje egyes betegségekben, másrészt az azokat kialakító, specifikus tényezők meghatározása, feltárása. Ehhez hozzátartozik, hogy ne csak a pszichológiai tényezők szerepeljenek a tanulmányok témáiként, hanem a pszichológiai múködésmódok, pszichodinamizmusok is. Ezek az információk értékesek lehetnek a gyógyítás szempontjából. Itt jegyezzük meg, hogy munkacsoportunk jelenleg egy ilyen átfogó vizsgálaton dolgozik, amely a fent hivatkozott jelenségeknek a Sjögren-szindrómára jellemző kiváltó okait kutatja nagy betegmintán.

A leírtak alapján Sjögren-szindrómában is igazolódni látszik az Engel által javasolt és az Egészségügyi Világszervezet által alkalmazott biopszichoszociális egészségmodell [66]. A Sjögren-szindróma látványosan illeszkedik ebbe a modellbe, a biológiai, pszichológiai és pszichoszociális/szociális tényezők gazdag kölcsönhatásrendszerében értelmezhető betegség képét mutatja. Ennek a rendszernek a megismeréséhez olyan longitudinális vizsgálatok elvégzésére lenne szükség, amelyek feltárják az egészségdimenziók közti komplex relációkat. Ez az egészségmodell napjainkra kibővült egy újabb tényezővel, a spiritualitással, így biopszichoszociospirituális modellról beszélhetünk [67, 68]. A Sjögren-szindrómára jellemző lelki jellegzetességek terén végzett vizsgálatok egyik hiányossága, hogy nem történt olyan kutatás, amely a pSS-betegek spiritualitását veszi górcső alá. Ez lehet a pSS pszichológiai kutatásának egy új iránya.
Következtetésként levonhatjuk továbbá, hogy a biopszichoszociális/biopszichoszociospirituális szemlélet a betegellátásban is fontos, hiszen ezen tényezók figyelembevételével a gyógyítás során a betegek teljesebb, átfogóbb egészséghez, életminőséghez juthatnak. Ennek érdekében az első gyakorlati lépés lehet egy olyan biopszichoszociospirituális leltárkérdőív elkészítése, amely segítséget nyújt az egészségügyi szakdolgozóknak a beteg problémáiról széleskörúen tájékozódni. Emellett a pSS-betegek gyógyításában részt vevők szemléletének tágítása, a pszichés, szociális, esetleges spirituális tényezőkre való figyelemfelhívás is jó irány lehet a betegek jólléte felé. A fent említett egészségmodell egyik ismérve az intencionalitás, azaz a beteg akaratlagos részvétele saját gyógyításában, gyógyulásában. A pszichés zavarok, pszichopatológiai tünetek kezelésére rendelkezésre állnak terápiás megoldások, amelyeket a betegek igénybe vehetnek saját gyógyulásuk érdekében. Ezért nemcsak a professzionális személyzet, hanem a betegek oktatása, pszichoedukációja is fontos a pSS-sel való küzdelemben.

A primer Sjögren-szindróma komplex betegség, amelyet sok pszichológiai tényező befolyásol, így a szakemberek és a betegek részéról is fontos a betegség lelki hátterének figyelembevétele, hogy így átfogóbb egészségélményben lehessen része annak, aki ebben a betegségben szenved.

Anyagi támogatás: A közlemény megírása, illetve a kapcsolódó kutatómunka anyagi támogatásban nem részesült.

Szerzői munkamegosztás: V. M. L.: A szakirodalom áttekintése, a kézirat elkészítése, a táblázatok szerkesztése. Sz. A.: A kézirat javítása, a klinikai adatok ellenőrzése, hozzáadása. B. A.: A téma kiválasztása, a kézirat javítása, a pszichológiai adatok ellenőrzése, hozzáadása. A cikk végleges változatát valamennyi szerző elolvasta és jóváhagyta.

Érdekeltségek: A szerzőknek nincsenek érdekeltségeik.

\section{Irodalom}

[1] Moutsopoulos HM, Kordossis T. Sjögren's syndrome revisited: autoimmune epithelitis. Br J Rheumatol. 1996; 35: 204-206.

[2] Binard A, Devauchelle-Pensec V, Fautrel B, et al. Epidemiology of Sjögren's syndrome: where are we now? Clin Exp Rheumatol. 2007; 25: 1-4.

[3] Mavragani CP, Moutsopoulos HM. The geoepidemiology of Sjögren's syndrome. Autoimmun Rev. 2010; 9: A305-A310.

[4] Qin B, Wang J, Yang Z, et al. Epidemiology of primary Sjögren's syndrome: a systematic review and meta-analysis. Ann Rheum Dis. 2015; 74: 1983-1989.

[5] Alexander F. Psychosomatic medicine: its principles and applications. W W Norton \& Co., New York, NY, 1950.

[6] Solomon GF. Psychoneuroimmunology: interactions between central nervous system and immune system. J Neurosci Res. 1987; 18: 1-9 
[7] Sturgeon JA, Finan PH, Zautra AJ. Affective disturbance in rheumatoid arthritis: psychological and disease-related pathways. Nat Rev Rheumatol. 2016; 12: 532-542.

[8] Pryce CR, Fontana A. Depression in autoimmune diseases. In: Geyer MA, Ellenbroek BA, Marsden CA, et al. (eds.) Current topics in behavioral neurosciences. Springer Verlag, Cham, 2016; pp. 139-154.

[9] Oláh Cs, Schwartz N, Denton C, et al. Cognitive dysfunction in autoimmune rheumatic diseases. Arthritis Res Ther. 2020; 22: 78.

[10] Berner C, Erlacher L, Fenzl KH, et al. A cross-sectional study on self-reported physical and mental health-related quality of life in rheumatoid arthritis and the role of illness perception. Health Qual Life Outcomes 2018; 16: 238.

[11] Karademas EC, Ktistaki G, Dimitraki G, et al. Adaptation to an autoimmune disorder: does mental flexibility impact illness-related self-regulation? Psychol Health 2016; 31: 276-291.

[12] Ward DJ. Rheumatoid arthritis and personality: a controlled study. Br Med J. 1971; 2(5757): 297-299.

[13] Marcenaro M, Prete C, Badini A, et al. Rheumatoid arthritis, personality, stress response style, and coping with illness. A preliminary study. Ann N Y Acad Sci. 1999; 876: 419-425.

[14] Donisan T, Bojincă VC, Dobrin MA, et al. The relationship between disease activity, quality of life, and personality types in rheumatoid arthritis and ankylosing spondylitis patients. Clin Rheumatol. 2017; 36: 1511-1519.

[15] Ko KM, Moon SJ, Koh JH, et al. Contribution of personality traits, psychological factors, and health-related quality of life to medication adherence in patients with rheumatoid arthritis. Yonsei Med J. 2020; 61: 406-415.

[16] Bucourt E, Martaillé V, Mulleman D, et al. Comparison of the Big Five personality traits in fibromyalgia and other rheumatic diseases. Jt Bone Spine 2017; 84: 203-207.

[17] Milic V, Grujic M, Barisic J, et al. Personality, depression and anxiety in primary Sjogren's syndrome - Association with sociodemographic factors and comorbidity. PLoS ONE 2019; 14: e0210466.

[18] Olofsson PS, Rosas-Ballina M, Levine YA, et al. Rethinking inflammation: neural circuits in the regulation of immunity. Im munol Rev. 2012; 248: 188-204.

[19] Martelli D, McKinley MJ, McAllen RM. The cholinergic antiinflammatory pathway: a critical review. Auton Neurosci. 2014; 182: 65-69.

[20] Szpunar MJ, Belcher EK, Dawes RP, et al. Sympathetic innervation, norepinephrine content, and norepinephrine turnover in orthotopic and spontaneous models of breast cancer. Brain Behav Immun. 2016; 53: 223-233.

[21] Madden KS, Felten SY, Felten DL, et al. Sympathetic neural modulation of the immune system. I. Depression of T cell immunity in vivo and in vitro following chemical sympathectomy. Brain Behav Immun. 1989; 3: 72-89.

[22] Marino F, Cosentino M. Adrenergic modulation of immune cells: an update. Amino Acids 2013; 45: 55-71.

[23] Micale V, Drago F. Endocannabinoid system, stress and HPA axis. Eur J Pharmacol. 2018; 834: 230-239.

[24] Johnson EO, Vlachoyiannopoulos PG, Skopouli FN, et al. Hypofunction of the stress axis in Sjögren's syndrome. J Rheumatol. 1998; 25: 1508-1514

[25] Hannestad J, Gallezot JD, Schafbauer T, et al. Endotoxin-induced systemic inflammation activates microglia: $\left[{ }^{11} \mathrm{C}\right] \mathrm{PBR} 28$ positron emission tomography in nonhuman primates. Neuroimage 2012; 63: 232-239.

[26] Talabér G, Jondal M, Okret S. Extra-adrenal glucocorticoid synthesis: immune regulation and aspects on local organ homeostasis. Mol Cell Endocrinol. 2013; 380: 89-98.

[27] Konttinen YT, Porola P, Konttinen L, et al. Immunohistopathology of Sjögren's syndrome. Autoimmun Rev. 2006; 6: 16-20.
[28] Carlsten H, Nilsson N, Jonsson R, et al. Estrogen accelerates im mune complex glomerulonephritis but ameliorates $\mathrm{T}$ cell-mediated vasculitis and sialadenitis in autoimmune MRL lpr/lpr mice. Cell Immunol. 1992; 144: 190-202.

[29] Ishimaru N, Saegusa K, Yanagi K, et al. Estrogen deficiency accelerates autoimmune exocrinopathy in murine Sjogren's syndrome through Fas-mediated apoptosis. Am J Pathol. 1999; 155: 173-181.

[30] Konttinen YT, Fuellen G, Bing Y, et al. Sex steroids in Sjögren's syndrome. J Autoimmun. 2012; 39: 49-56.

[31] Liu WH, Chen Y, Bai XW, et al. Identification and characterization of a novel neuropeptide (neuropeptide Y-HS) from leech salivary gland of Haemadipsa sylvestris. Chin J Nat Med. 2016; 14: 677-682.

[32] Hauk V, Calafat $M$, Grasso E, et al. Neuroimmune aspects of Sjogren's syndrome: role of VIP/VPAC system in immune and salivary gland epithelial cell function. Curr Pharm Des. 2014; 20: $4760-4765$.

[33] Li C, Zhu F, Wu B, Wang Y. Vasoactive intestinal peptide protects salivary glands against structural injury and secretory dysfunction via IL-17A and AQP5 regulation in a model of Sjögren syndrome. Neuroimmunomodulation 2014; 24: 300-309.

[34] Herman JP, McKlveen JM, Ghosal S, et al. Regulation of the hypothalamic-pituitary-adrenocortical stress response. Compr Physiol. 2016; 6: 603-621.

[35] Harboe E, Tjensvoll AB, Vefring HK, et al. Fatigue in primary Sjögren's syndrome - a link to sickness behaviour in animals? Brain Behav Immun. 2009; 23: 1104-1108.

[36] Dantzer R. Neuroimmune interactions: from the brain to the immune system and vice versa. Physiol Rev. 2018; 98: 477-504.

[37] Konsman JP, Veeneman J, Combe C, et al. Central nervous action of interleukin-1 mediates activation of limbic structures and behavioural depression in response to peripheral administration of bacterial lipopolysaccharide. Eur J Neurosci. 2008; 28: 24992510.

[38] Beattie EC, Stellwagen D, Morishita W, et al. Control of synaptic strength by glial TNF $\alpha$. Science $2002 ; 295: 2282-2285$.

[39] Malinow KL, Molina R, Gordon B, et al. Neuropsychiatric dys function in primary Sjogren's syndrome. Ann Intern Med. 1985; 103: $344-350$

[40] Valtýsdóttir ST, Gudbjörnsson B, Lindqvist U, et al. Anxiety and depression in patients with primary Sjogren's syndrome. J Rheumatol. 2000; 27: 165-169.

[41] Mitsikostas DD, Doskas T, Gkatzonis S, et al. A prospective, observational, cohort study to assess the efficacy and safety of prolonged-release fampridine in cognition, fatigue, depression, and quality of life in multiple sclerosis patients: the FAMILY study. Adv Ther. 2021; 38: 1536-1551.

[42] Maglione JE, Ancoli-Israel S, Peters KW, et al. Depressive symptoms and subjective and objective sleep in community-dwelling older women. J Am Geriatr Soc. 2012; 60: 635-643.

[43] Cui Y, Xia L, Li L, et al. Anxiety and depression in primary Sjögren's syndrome: a cross-sectional study. BMC Psychiatry 2018; 18: 131

[44] Champey J, Corruble E, Gottenberg JE, et al. Quality of life and psychological status in patients with primary Sjögren's syndrome and sicca symptoms without autoimmune features. Arthritis Rheum. 2006; 55: 451-457.

[45] Milin M, Cornec D, Chastaing M, et al. Sicca symptoms are associated with similar fatigue, anxiety, depression, and quality-oflife impairments in patients with and without primary Sjögren's syndrome. Joint Bone Spine 2016; 83: 681-685.

[46] Segal BM, Pogatchnik B, Holker E, et al. Primary Sjogren's syndrome: cognitive symptoms, mood and cognitive performance. Acta Neurol Scand. 2012; 125: 272-278.

[47] Stevenson HA, Jones ME, Rostron JL, et al. UK patients with primary Sjögren's syndrome are at increased risk from clinical depression. Gerodontology 2004; 21: 141-145. 
[48] Karaiskos D, Mavragani CP, Sinno MH, et al. Psychopathological and personality features in primary Sjögren's syndrome - associations with autoantibodies to neuropeptides. Rheumatology 2010; 49: 1762-1769.

[49] Shen CC, Yang AC, Kuo BI, et al. Risk of psychiatric disorders following primary Sjögren syndrome: a nationwide populationbased retrospective cohort study. J Rheumatol. 2015; 42: $1203-$ 1208.

[50] Rózsa S, Purebl G, Susánszky É, et al. Dimensions of coping: Hungarian adaptation of the Ways of Coping Questionnaire. [A megküzdés dimenziói: a Konfliktusmegoldó Kérdőív hazai adaptációja.] Mentalhig Pszichoszom. 2008; 9: 217-241. [Hungarian]

[51] Andersson SI, Manthorpe R, Theander E. Situational patterns in coping with primary Sjögren's syndrome. Psychol Health Med. 2001; 6: 29-40.

[52] Segal B, Bowman SJ, Fox PC, et al. Primary Sjögren's syndrome: health experiences and predictors of health quality among patients in the United States. Health Qual Life Outcomes 2009; 7: 46.

[53] van Leeuwen N, Bossema ER, Knoop H, et al. Psychological profiles in patients with Sjogren's syndrome related to fatigue: a cluster analysis. Rheumatology 2015; 54: 776-783.

[54] Karaiskos D, Mavragani CP, Makaroni S, et al. Stress, coping strategies and social support in patients with primary Sjogren's syndrome prior to disease onset: a retrospective case-control study. Ann Rheum Dis. 2009; 68: 40-46.

[55] Leavitt F. The value of the MMPI conversion "V" in the assessment of psychogenic pain. J Psychosom Res. 1985; 29: 125131.

[56] Lachar D. MMPI: Clinical Assessment and Automated Interpretation (WPS professional handbook series). Western Psychological Services, 1974.

[57] Hietaharju A, Yli-Kerttula U, Häkkinen V, et al. Nervous system manifestations in Sjögren's syndrome. Acta Neurol Scand. 1990; 81: 144-152.

[58] Harboe E, Tjensvoll AB, Maroni S, et al. Neuropsychiatric syndromes in patients with systemic lupus erythematosus and primary Sjögren syndrome: a comparative population-based study. Ann Rheum Dis. 2009; 68: 1541-1546.
[59] Epstein LC, Masse G, Harmatz JS, et al. Characterization of cog nitive dysfunction in Sjögren's syndrome patients. Clin Rheumatol. 2014; 33: 511-521.

[60] Segal BM, Pogatchnik B, Rhodus N, et al. Pain in primary Sjögren's syndrome: the role of catastrophizing and negative illness perceptions. Scand J Rheumatol. 2014; 43: 234-241.

[61] Kotsis K, Voulgari PV, Tsifetaki N, et al. Illness perceptions and psychological distress associated with physical health-related quality of life in primary Sjögren's syndrome compared to systemic lupus erythematosus and rheumatoid arthritis. Rheumatol Int. 2014; 34: 1671-1681.

[62] Isik H, Isik M, Aynioglu O, et al. Are the women with Sjögren's syndrome satisfied with their sexual activity? Rev Bras Reumatol. 2017; 57: 210-216.

[63] Carsons SE, Vivino FB, Parke A, et al. Treatment guidelines for rheumatologic manifestations of Sjögren's syndrome: use of biologic agents, management of fatigue, and inflammatory musculoskeletal pain. Arthritis Care Res. 2017; 69: 517-527.

[64] Meijer JM, Meiners PM, Huddleston Slater JJ, et al. Health-related quality of life, employment and disability in patients with Sjögren's syndrome. Rheumatology 2009; 48: 1077-1082.

[65] Liu Z, Dong Z, Liang X, et al. Health-related quality of life and psychological status of women with primary Sjögren's syndrome: a cross-sectional study of 304 Chinese patients. Medicine (Baltimore) 2017; 96: e9208.

[66] Engel GL. The need for a new medical model: a challenge for biomedicine. Science 1977; 196: 129-136.

[67] Marks L. Religion and bio-psycho-social health: a review and conceptual model. J Relig Health 2005; 44: 173-186.

[68] Leukefeld CG, Leukefeld S. Primary socialization theory and a bio/psycho/social/spiritual practice model for substance use. Subst Use Misuse 1999; 34: 983-991.

(Módis László dr., Debrecen, Nagyerdei krt. 98., 4032 e-mail: modis.laszlo6@med.unideb.hu)

\section{"Amare et sapere vix deo conceditur." (A bölcs szeretet még egy istennél is ritka adomány.)}

A cikk a Creative Commons Attribution 4.0 International License (https://creativecommons.org/licenses/by/4.0/) feltételei szerint publikált Open Access közlemény, melynek szellemében a cikk bármilyen médiumban szabadon felhasználható, megosztható és újraközölhető, feltéve, hogy az eredeti szerző és a közlés helye, illetve a CC License linkje és az esetlegesen végrehajtott módositások feltüntetésre kerülnek. (SID_1) 